\title{
New records of the myxomycetes from Mona Island, Puerto Rico',2
}

\author{
Angel M. Nieves-Rivera $\alpha^{3}$ and Carlos J. Santos-Flores ${ }^{4}$
}

\author{
J. Agric. Univ. P.R. 82(8-4):189-199 (1998)
}

\section{ABSTRACT}

Seven species of myxomycetes are reported as new records for the Mona Island Commonweaith Reserve, Puerto Rico. They are Ceratiomyxa, fruticulosa, Crlbaria Intricata, Dictydium cancellatum, Fuligo septica, Ly. cogala sp., Stemonills axifora and Tublfera ferruginosa.

Key words: Slime molds, myxomycetes, mycoblota, protozoa, Mona Island, Puerto Rico

\section{RESUMEN}

Nuevos registros de los mixomicetos de Isla de Mona, Puerto Rico

Slete especies de mixomicetos son informados como nuevos registros para la Reserva Estatal Isla de Mona, Puerto Rico. Estos son Ceratiomyxa fruticulosa, Cribaria intricata, Dictydlum cancellatum, Fullgo septica, Ly. cogala sp., Stemonitis axifera y Tubifera ferruginosa.

\section{INTRODUCTION}

Previous work on the myxomycetes of the island of Puerto Rico began with Hagelstein (1927), who catalogued 23 species. Five years later, he added about 37 species from Puerto Rico and the Virgin Islands (Hagel-

'Manuscript submitted to Editorial Board 25 August 1997.

2Acknowledgments: Funding for this research was provided by the Seed Money Grant Program (R\&D Center, UPR, Mayagutez.) We thank Mrs. Wendy Boneta of the Puerto Rico Department of Natural and Environmental Resources for granting permission to collect on Mona Island (DRN-95-18). We are greatful to Drs. D. Jean Lodge (USDA/FSFPL Luquillo) and Carlos Betancourt (UPR, Mayagüez) for allowing us access to their laboratories and equipment. We appreciate corrections made to the text by Drs. Lois $\mathrm{H}$. Tiffany (Iowa State Univ, Ames), Paul Bayman (UPR, Rfo Piedras), Gastón Guzmán (Instituto de Ecologia, Mexico) and Steven L. Stephenson (Fairmont State College, West Virginia). Finally, we thank Mr. Caxlos M. Ortiz (Mayagtiez), who shared with us his impressions of Mona Island while he worked for the Civilian Conservation Corps (CCC) in 1987.

'Center for Forest Mycology Research, USDA/Forest Service, Forest Products Laboratory, P, O. Box 1377, Luquillo, P. R. 00773 USA. Present address: Department of Marine Sciences, University of Puerto Rico, Mayagliez, P. R. $00681-9013$ (or P. O. Box 908, Lajas, PR 00667).

Oceanography and Limnology Program, University of Wisconsin-Madison, Madison, W 63703. 
stein, 1932). New records of this group of organisms were made by Alexopoulos (1970), Stevenson (1975), Lodge (1996) and Stephenson (1996). These records were based on collections by Alexopoulos, Lodge, and Stephenson at El Verde in the Luquillo Mountains. A total of 70 species of myxomycetes have been reported for the island of Puerto Rico. Mycological surveys of Mona Island carried out by Britton (1915), Seaver and Chardón (1926) and Stevenson (1975) did not record the presence of any myxomycetes. It is our intention to update the list of myxomycetes recorded from Puerto Rico, in particular the mycobiota of Mona Island.

\section{MATERIALS AND METHODS}

\section{Study area}

Mona Island Commonwealth Reserve (18 $8^{\circ} 38^{\prime} \mathrm{N}$ and $67^{\circ} 51-57^{\prime} \mathrm{W}$ ) is a $55-\mathrm{km}^{2}$ carbonate platform in the middle of the Mona Passage, $68 \mathrm{~km}$ west of Punta Higüero, Puerto Rico, and $60 \mathrm{~km}$ east of Punta Espada, Dominican Republic. According to Ewel and Whitmore (1973), Mona Island is catalogued as a subtropical dry forest life zone. Mean annual precipitation ranges from 600 to $1,200 \mathrm{~mm}$ and the mean annual temperature is 24 to $28^{\circ} \mathrm{C}$ (Calvesbert, 1973; Wiewandt, 1977).

Mona Island's climate has been described as subtropical dry or that of a typical offshore Puerto Rican island, with scanty rain and marine conditions (Ewel and Whitmore, 1973; Wiewandt, 1977). In general, there are two distinct rainy seasons on Mona Island, one May to June; the other, August to November. Summer and autumn months tend to be more or less rainy, whereas the winter and spring months are usually drier (Nieves-Rivera, 1996).

Transportation to the island was coordinated with the Puerto Rico Department of Natural and Environmental Resources. Specimens were collected at random along the trails of the Island. Microscopic observations were made using material mounted on slides in $3 \% \mathrm{KOH}$ or lactophenol. Drawings were made at $40 \times, 60 \times$ and $100 \times$ with the aid of a drawing tube (Nikon, Inc.). Identifications were based on Martin and Alexopoulos (1969) and Farr (1976). Nomenclature for vascular plants was based on Woodbury et al. (1977). Color names are given according to Kornerup and Wanscher (1978). Collections were deposited in the Cryptogamic Herbarium, The New York Botanical Garden, New York (NY), the Tropical Mycology Collection of the Department of Biology, Mayagiuez (MAPR) or temporarily curated at the Center for Forest Mycology Research, Luquillo, PR (CFMR), before being deposited at the Herbarium of the Department of Biology, University of Puerto Rico, Río Piedras (UPRRP). 


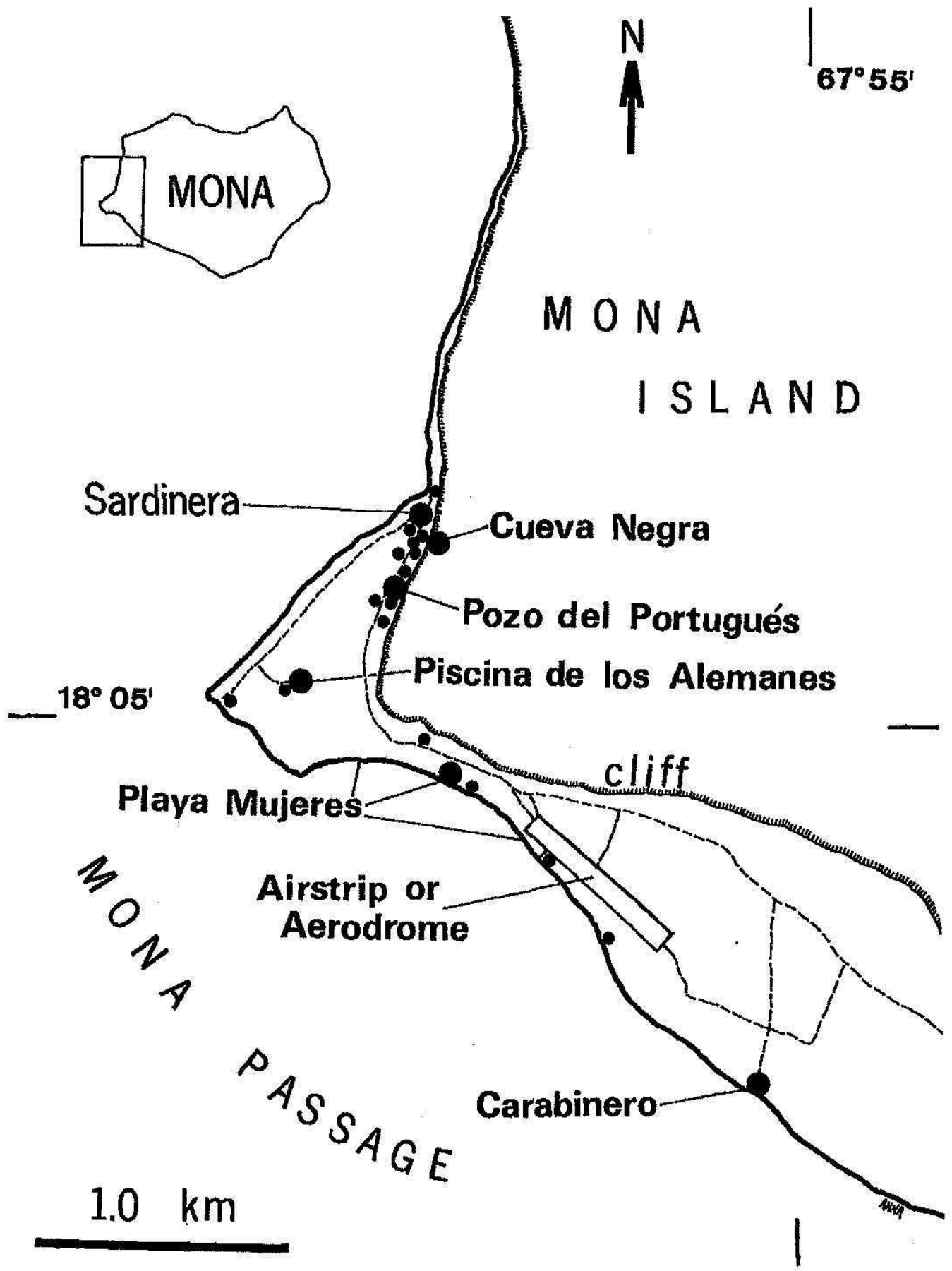

FrgURE 1. Map of collection sites at Mona Island Commonwealth Reserve, Puerto Rico $(\Theta=$ research natural area; $\bullet=$ incidental site). 


\section{RESULTS}

Seven species of myxomycetes were collected by the senior author, mostly between Sardinera and Pozo del Portugués, Piscina de los Alemanes, Playa Mujeres and near the airstrip (or aerodrome) (Figure 1). Pure cultures were not attempted because of the lack of fresh plasmodia in some collections and the fast growth rate of contaminants (bacteria, molds and yeasts).

Species collected

Ceratiomyxa fruticulosa (O. F. Müll.) T. Macbr., 1899

(Figures 2A-D)

Fructifications 1.2 $\times 1.3 \mathrm{~mm}$, clavaroid, unbranched, unstalked, smooth, white and brownish red to greyish red (Figures 2A, B). Columns (or erect columns) 12-25 $\mu \mathrm{m}$ diam, long branched tubes with transverse folds and wrinkles, minutely spinulose, hyaline (Figure 2C). Spores 10-11 $\times$ 6-6.5 $\mu \mathrm{m}$, globose, ovoid, sometimes elliptical, smooth, thin-walled, hyaline (Figure 2D). Plasmodium hyaline.

Habitat. Gregarious on dead petioles and fruits of Cocos nucifera $\mathrm{L}$. (Palmaceae) and decayed wood of Casuarina equisetifolia J. R. \& Forst. (Casuarinaceae).

Material studied. MONA ISLAND: Sardinera, on trail to Cueva Negra, 2-m alt., 26 August 1995, Nieves-Rivera PR 9 (CFMR); NievesRivera PR 10 (NY); near Pozo del Portugués, 2-m alt., 25 August 1995, Nieves-Rivera PR 15 (CFMR).

\section{Cribaria intricata Schrad., 1797}

\section{(Figures 2E-G)}

Sporangia $2-4 \times 0.5-0.7 \mathrm{~mm}$, stipitate, nodding or erect, globose, yellowish brown to dark brown (Figure 2E). Calyculus discoid to bowllike, strongly ribbed, with dentate margin; reticulum regular, with trapezoid meshes, and consisting of prominent, dark, thick, polygonal or branching nodes, each with 5-6 connecting filaments (Figure 2F). Stalk 2-3 mm long, slender, tapering or not upward, curved to twisted at top, dark brown. Dictydine granules small, light brown to brown. Spores 3.5-5 $\mu \mathrm{m}$ diam, globose, with minute spines, thin or thick-walled, light brown (Figure 2G). Plasmodium yellowish brown or brown.

Habitat. Gregarious on decayed logs, dead twigs, leaves and fruits of Casuarina equisetifolia.

Material studied. MONA ISLAND: Sardinera, near house M-2, 2m alt., 29 June 1995, Nieves-Rivera PR 5 (CFMR); near Pozo del Portugués, 2-m alt., 28 August 1995, Nieves-Rivera PR 7 (MAPR); NievesRivera PR 13 (NY). 

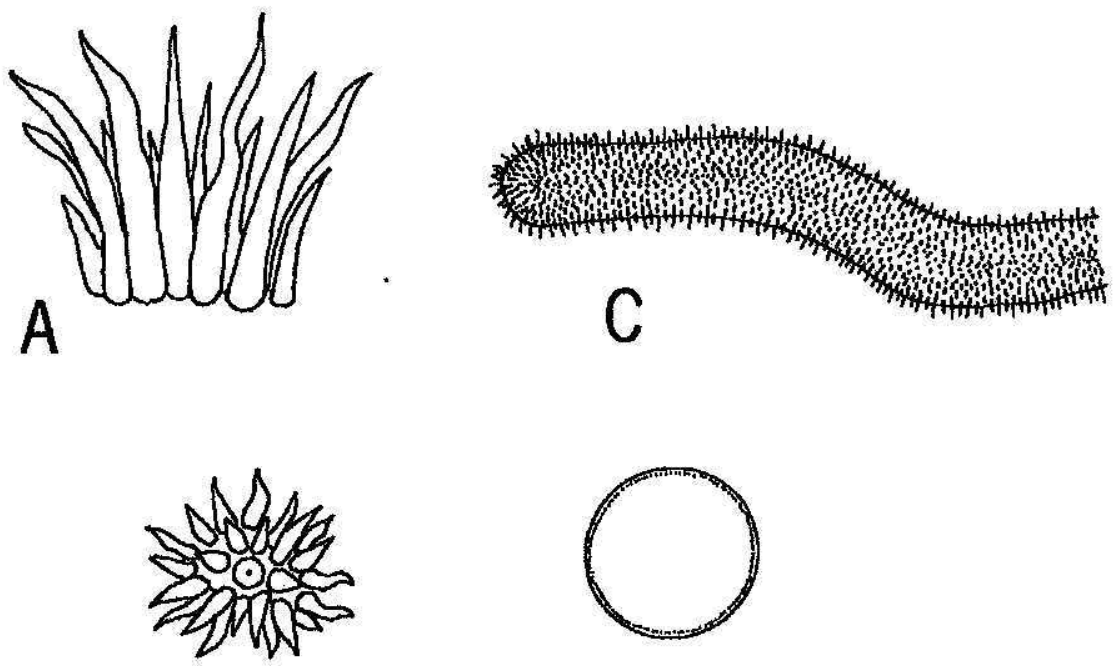

B

D
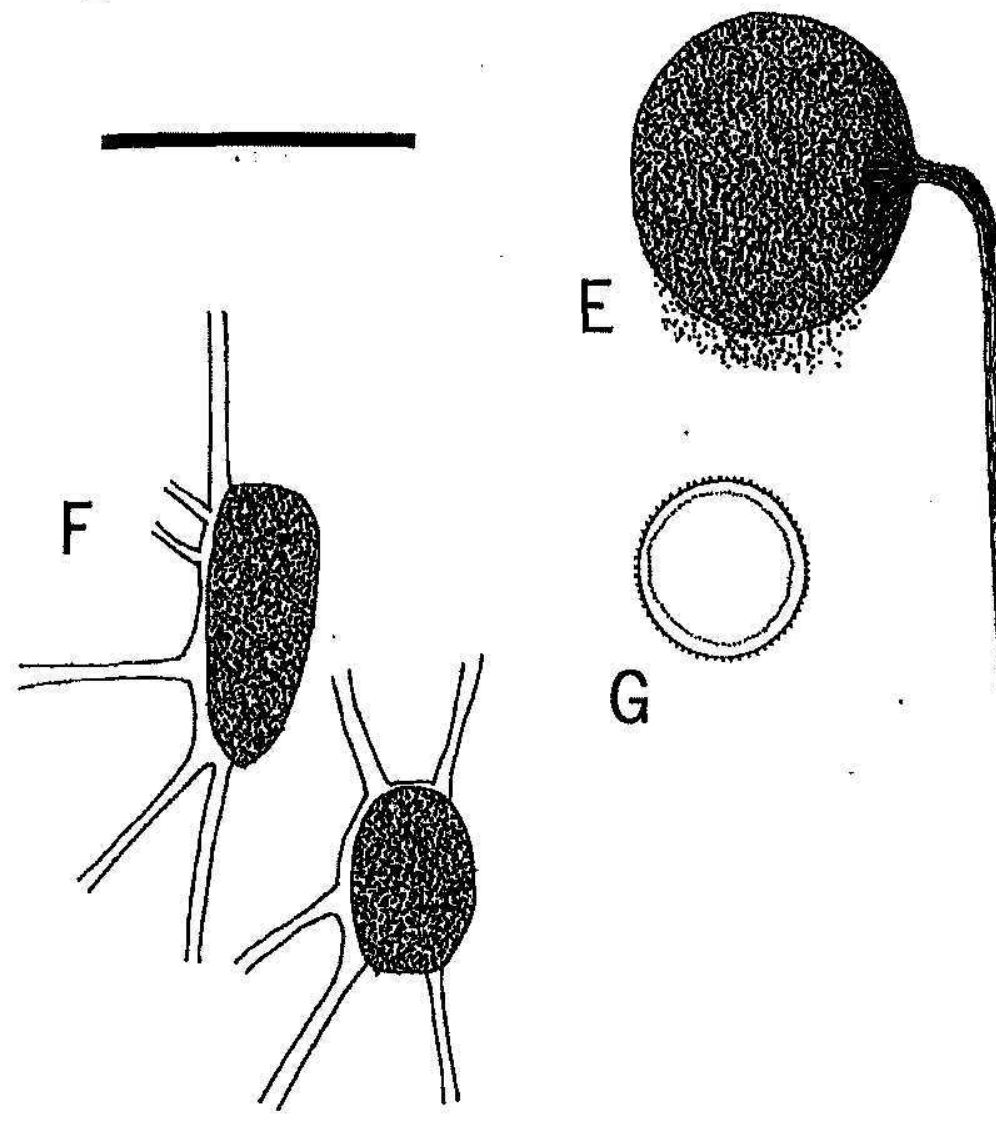

FTGURE 2. A-D Ceratiomyxa fruticulosa. A. Fructifications. B. Top view of fructifications. C. Column. D. Spore. E-G Cribaria intricata. E. Sporangium. F. Nodes (part of net). G. Spore. Scale bar $=1.5 \mathrm{~mm}$ for $A ; 1 \mathrm{~mm}$ for $B ; 15 \mu \mathrm{m}$ for $C ; 19 \mu \mathrm{m}$ for $D ; 1 \mathrm{~mm}$ for $E ; 15$ $\mu \mathrm{m}$ for $\mathrm{F} ; 8 \mu \mathrm{m}$ for $\mathrm{G}$. 
Dictydium cancellatum (Batsch) T. Macbr., 1899

\section{(Figures 3A-C)}

Sporangia $2-4 \times 0.5-1 \mathrm{~mm}$, stipitate nodding, globose to depressedglobose, umbilicate below and sometimes above, reddish brown to
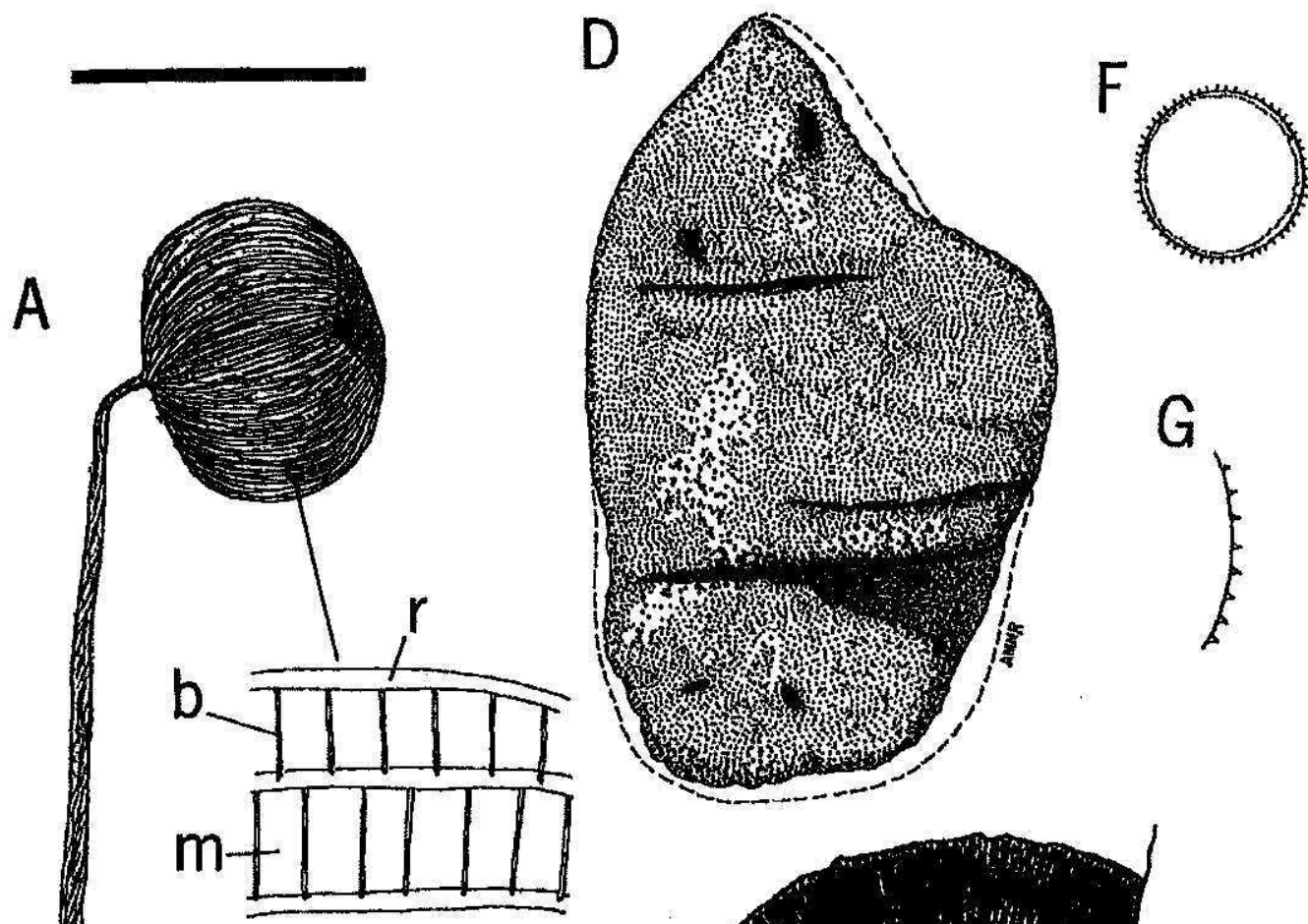

B
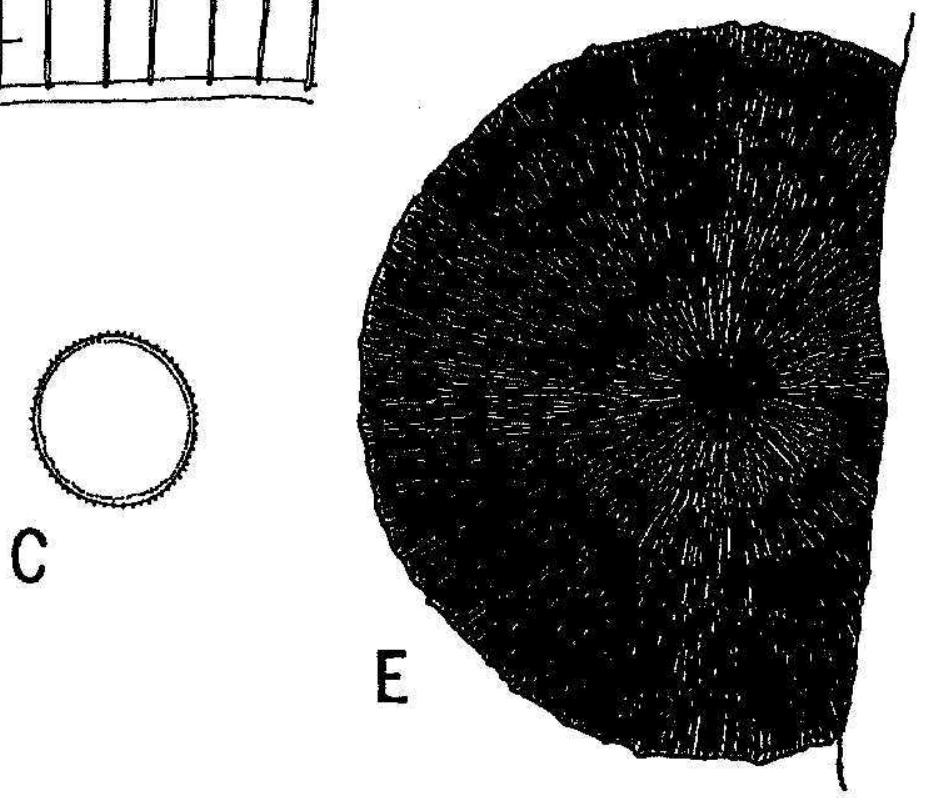

FIGURE 3. A-C Dictydium cancellatum. A. Sporangium. B. Detail of net ( $\mathrm{b}=\mathrm{bands}$ $\mathrm{m}=\mathrm{mesh} ; \mathbf{r}=$ ribs). C. Spore. D-G Fuligo septica. D. Aethalium. E. Cross section of aethalium. F. Spore. G. Detail of spore surface. Scale bar $=1 \mathrm{~mm}$ for $A ; 5 \mu \mathrm{m}$ for $B ; 5.8 \mu \mathrm{m}$ for $\mathrm{C} ; 6 \mathrm{~cm}$ for $\mathrm{D} ; 2 \mathrm{~cm}$ for $\mathrm{E} ; 14 \mu \mathrm{m}$ for $\mathrm{F} ; 3 \mu \mathrm{m}$ for $\mathrm{G}$. 
brown (Figure 3A). Peridium membranous, delicate, thickened in the form of stout longitudinal ribs (Figure $3 \mathrm{~B}, \mathrm{r}$ ), connected by delicate transverse bands (Figure 3B, b), 0.9-1.4 $\mu \mathrm{m}$ apart, meshes (Figure 3B, $\mathrm{m}$ ) rectangular in shape and irregular at apex and base, reddish brown to brown. Calyculus absent. Stalk 1-3 mm long, subulate, curved to twisted at top, tapering upward, brown. Spores 4.9-5.2 $\mu \mathrm{m}$ diam, globose, minutely verrucose or smooth, thin-walled, light brown (Figure 3C). Plasmodium not seen.

Habitat. Solitary or gregarious with Cribaria intricata on dead wood of Casuarina equisetifolia and on unidentified decayed wood.

Material studied. MONA ISLAND: Sardinera, on trail to Cueva Negra, 2-m alt., 28 August 1995, Nieves-Rivera PR 286 (CFMR).

\section{Fuligo septica (L.) F. H. Wigg., 1780}

\section{(Figures 3D-G)}

Aethalia 13-19 $\times 2-5.5 \mathrm{~cm}$, pulvinate, dusty, fragile, rarely calcareous, brownish orange, reddish brown, brown, white, greyish blue, and golden yellow (Figures 3D, E). Cortex membranous, thick, fragile, hyaline. Hypothallus consisting of one or more layers, brownish orange, reddish brown. Capillitium composed of hyaline filaments, without nodes. Spores 7-9 $\mu \mathrm{m}$ diam, globose, minutely spinulose, thin-walled, brown to light brown (Figures 3F, G). Plasmodium yellow to golden yellow.

Habitat. Solitary or sometimes gregarious on decayed log and branches of Casuarina equisetifolia and also occurring on unidentified living trees.

Material studied. MONA ISLAND: Camino Sardinera, near trail to Cueva Negra, 2.5-m alt., 26 March 1995, Nieves-Rivera PR 107 (NY); near house M-2, 2-m alt., 26 March 1995, Nieves-Rivera PR 108 (MAPR); near water pump (Pozo del Portugués), 2-m alt., 26 March 1995, Nieves-Rivera PR 157 (NY); 21 April 1995, Nieves-Rivera PR 207 (CFMR); Playa Mujeres, near the beach (approx. $9 \mathrm{~m}$ from shoreline), 2.7-m alt., 26 March 1995, Nieves-Rivera PR 160 (MAPR); near aerodrome, 1.5-m alt., 1 June 1995, Nieves-Rivera PR 162 (CFMR); Punta Arenas, near the road to Piscina de los Alemanes, 3-m alt., 1 June 1995, Nieves-Rivera PR 161 (NY); 2-m alt., 6 April 1995, Nieves-Rivera PR 199 (CFMR).

Remarks. The senior author observed ants inhabiting aethalium of F. septica, collection Nieves-Rivera PR 157 (NY), on a unidentified living tree. In collections Nieves-Rivera PR 107 (MAPR), 161 (NY), 162, 199 and 207 (CFMR), aethalia developed on dead or decayed basidiocarps of Hexagonia hydnoides (Fr.:Sw.) M. Fidalgo (Polyporaceae/ 
A
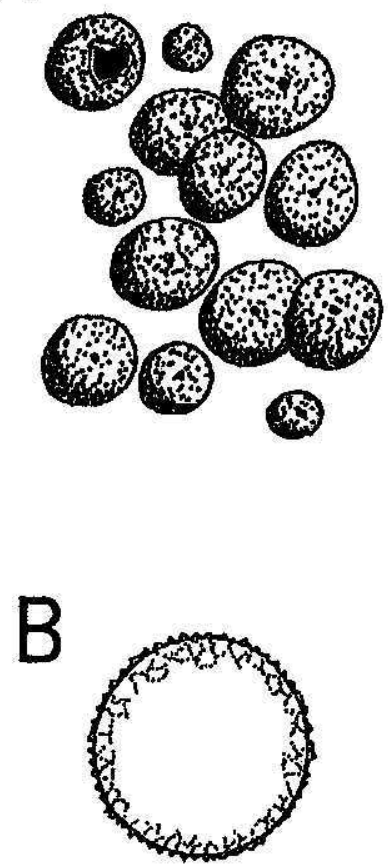

C

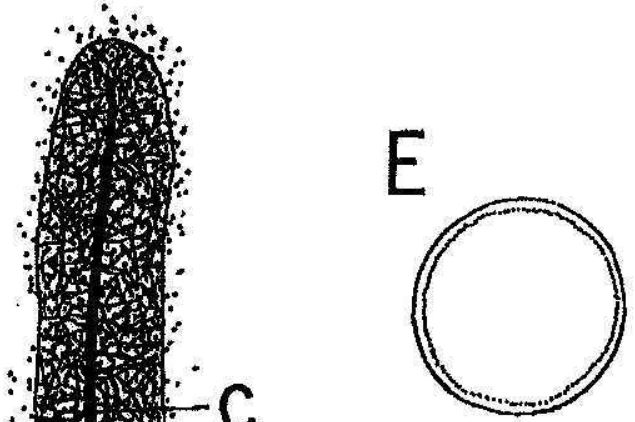

D

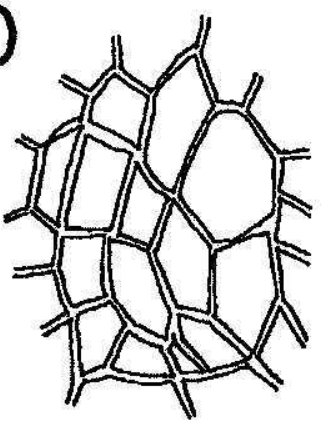

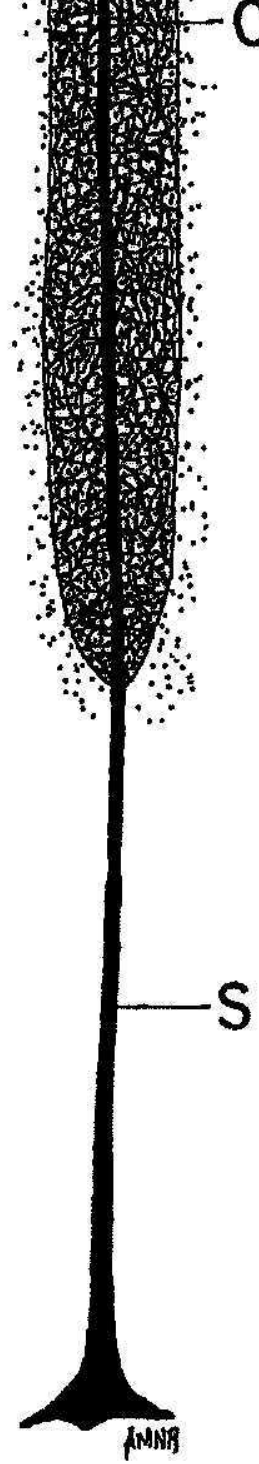

$\mathrm{S}$

$G$

$F$

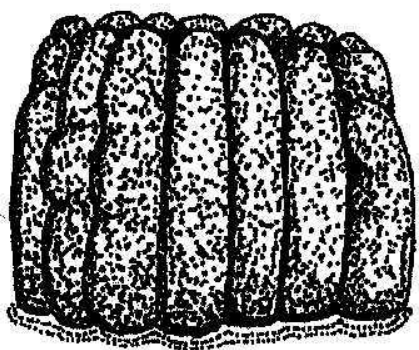

$\mathrm{H}$

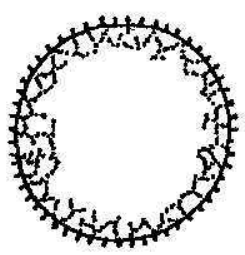

Frgurt 4. A-B Ijcogala sp. A. Cluster of aethalia, one dehiscent. B. Spore. C-E Stemonitis axifera. C. Sporangium ( $\mathrm{c}=$ columella; $\mathrm{s}=$ stalk). D. Detail of net. E. Spore. F-H Thubifera ferruginosa. F. Sporangia. G. Top view of sporangia. H. Spore. Scale bar a $=3.5$ $\mathrm{mm}$ for $A ; 10 \mu \mathrm{m}$ for $B ; 2.5 \mathrm{~mm}$ for. $C ; 60 \mu \mathrm{m}$ for $D ; 12 \mu \mathrm{m}$ for $E ; 6 \mathrm{~mm}$ for $F ; 15 \mathrm{~mm}$ for $\mathrm{G} ; 13 \mu \mathrm{m}$ for $\mathrm{H}$. 
Coriolaceae), Phellinus dependens (Murrill) Imaz., and Phylloporia chrysita (Berk.) Ryvarden (Hymenochaetaceae) (Nieves-Rivera, 1996).

\section{Lycogala sp.}

(Figures 4A-B)

Aethalia 0.5-3 mm diam, scattered to crowded, sessile, spherical or subglobose, depressed when ruptured, white to buff when fresh, then brown or dark brown (Figure 4A). Hypothallus membranous, hyaline to light brown. Pseudocapillitium consisting of tubules, these folded or wrinkled, originated from cortex. Cortex thin, rough or smooth, dehiscence at apex, brown to dark brown. Spores 5.5-7 $\mu \mathrm{m}$ diam, globose, reticulated over most of the surface, thin-walled, hyaline (Figure 4B). Plasmodium not seen.

Habitat. Gregarious on decayed petioles of Cocos nucifera and on a decayed log of Casuarina equisetifolia.

Material studied. MONA ISLAND: Sardinera, on trail to Cueva Negra, 2-m alt., 26 August 1995, Nieves-Rivera PR 11 (CFMR); NievesRivera PR 12 (MAPR).

Remarks. Aethalia smaller than $L$. epidendrum $(=3-15 \mathrm{~mm}$ diam), and without the purplish brown or black scales mentioned by Farr (1976). Mona Island specimens are similar to L. exiguum Morgan.

Stemonitis axifera (Bull.) T. Macbr., 1889

(Figures 4C-E)

Sporangia 7-8 (-9) $\mathrm{mm}$ long, cylindrical, stipitate, slender, acuminate, rounded at apex, brown or black (Figure 4C). Columella cylindrical, black (Figure 4C, c). Stalk $3.5 \mathrm{~mm}$ long, cylindrical, wider at base, black (Figure 4C, s). Capillitium branched free or even; reticulum smooth, uniform, and small polygonal meshes (Figure 4D). Spores 6-7 (-7.1) $\mu \mathrm{m}$ diam, globose, smooth or minutely equinulated, thin-walled, light brown (Figure 4E). Plasmodium white.

Habitat. Gregarious on a decayed wood Casuarina equisetifolia.

Material studied. MONA ISLAND: Sardinera, Pozo del Portugués, 2-m alt., 23 August 1995, Nieves-Rivera PR 3 (CFMR); NievesRivera PR 6 (NY).

Tubifera ferruginosa (Batsch) J. F. Gmel., 1791

(Figures 4F-H)

Sporangia 3-5 $\times$ 0.3-0.4 mm, cylindrical to elliptical, waxy, crowded, dehiscence apical, reddish brown (Figures 4F-G). Hypothal- 
lus broadly effused, spongy, not stipitate, hyaline. Pseudoaethalium as fragmented plates, $4-20 \mathrm{~mm}$ across, reddish brown to black when dried. Peridium thin, membranous, spongy, iridescent, hyaline. Spores 6.8-8 $\mu \mathrm{m}$ diam, globose, more or less reticulate, thin-walled, light brown to brown (Figure 4H). Plasmodium hyaline.

Habitat. Gregarious on dead wood of Terminalia catappa $\mathrm{L}$. (Combretaceae).

Material studied. MONA ISLAND: Camino Sardinera, close to dock (camp site), 2-m alt., 23 August 1995, Nieves-Rivera PR 8 (CFMR).

\section{DISCUSSION}

From the standpoint of collecting myxomycetes in regions with a dry climate, the level of moisture is the usual limiting factor rather than temperature. The myxomycetes from Mona Island were collected during March, June and August 1995. This year was unusual because of the even distribution of rainfall, modifying the usual pattern of wet and dry seasons. The distribution of myxomycetes on Mona Island was restricted to the coastal plain forest, close to Sardinera (Figure 1). The considerable high relative humidity $(60-80 \%)$ of this forest is due to the density of vegetation, oceanic influence (particularly climatic conditions, e.g., winds from the north) and natural brackish wells; it is considered a disturbed area, where vegetational changes have occurred.

According to Wadsworth (1977), Woodbury et al. (1977) and Ortiz (C. M. Ortiz, Quinto Centenario 856, El Maní, Mayagüez, PR, personal communication), in 1937 the Civilian Conservation Corps (CCC) planted some 264,000 trees [mostly Swietenia mahagoni Jacq. (Meliaceae), $\mathrm{Ca}$ suarina equisetifolia, and other cultivated plants] on the coastal plains of Sardinera, Carabinero, Uvero and on the plateau in Camino del Infierno and Los Caobos. Aerodrome (airstrip) construction and subsequent abandonment, as well as housing construction and periodic accidental fires have modified the native vegetation (Cintrón and Rogers, 1991). Myxomycetes collected on Mona Island occurred on dead and decayed plant material, especially on C. equisetifolia, Cocos nucifera and Terminalia cattapa. All of these are plants introduced to the island.

As previously indicated, mycological surveys of Mona Island neglected myxomycetes in their records. Mycologists who visited Mona Island were interested in the collection of other groups of fungi [e.g., pyrenomycetes (Ascomycota)] because of their phytopathological importance. On the other hand, previous mycological expeditions visited Mona in February and March (during the dry season), when the possibilities of recovering myxomycetes were considerably low. 
In conclusion, the species of myxomycetes found on Mona Island were cosmopolitan, grew on exotic vegetation, and were restricted to a humid zone. They were saprobes on dead and decayed material from introduced plants. The possibilities of myxomycetes in Mona Island are by no means exhausted, and future collections may produce some new records.

\section{ITTERATURE CITED}

Alexopoulos, C. J., 1970. Rain forest myxomycetes. In: Odum, H. T. and R. F. Pigeon (Eds). A tropical rain forest-a study of irradiation and ecology at El Verde, Puerto Rico, Appendix F. U. S. Atomic Energy Commission, Oak Ridge, Tennessee, pp. 21 23.

Britton, N. L., 1915. The vegetation of Mona Island.Ann Missouri Bot Gard 2:33-57.

Calvesbert, R. J., 1973. The climate of Mona Island. In: Junta de Calidad Ambiental (Ed). Mona and Monito Islands - an assessment of their natural and historical resources, Vol. 2, Appendix A. Oficina del Gobernador, San Juan, Puerto Rico, pp. 110,1 table.

Cintrón, B. and L. Rogers, 1991. Plant communities of Mona Island. Acta Cientifica 6:10-64.

Ewel, J. J. and J. L. Whitmore, 1973. The ecological life zones of Puerto Rico and the U.S. Virgin Islands. Forest Serv Res, Inst Tropical Forestry, Río Piedras, Puerto Rico.

Farr, M. L., 1976. Myxomycetes. Flora Neotropica Monography 16, New York Bot Gard, Bronx, New York.

Hagelstein, R., 1927. Mycetozoa from Puerto Rico. Mycologia 19:35-37.

Hagelstein, R., 1932. Revision of the Myxomycetes. Scientific Survey of Porto Rico and the Virgin Islands, Vol. 8 (Part 2). New York Acad Sci, New York, pp. 241-248.

Kornerup, A. and J. H. Wanscher, 1978. Methuen handbook of colour. 3rd ed. Eyre Methuen Ltd., London.

Lodge, D. J., 1996. Microorganisms. In: Reagan, D. P. and R. B. Waide (Eds), The food web of a tropical rain forest. Univ Chicago Press, Chicago, pp. 53-108.

Martin, G. W. and C. J. Alexopoulos, 1969. The Myxomycetes. Univ Iowa Press, Iowa City.

Nieves-Rivera, A. M., 1996. Hymenomycetes and gasteromycetes (Basidiomycotina) of Mona Island State Reserve, Puerto Rico (West Indies). M.S. Thesis, Univ Puerto Rico, Mayagilez, Puerto Rico.

Seaver, F. J. and C. E. Chardón, 1926. Mycology. Scientific Survey of Porto Rico and the Virgin Islands, Vol. 8 (Part, 1). New York Acad Sci, New York.

Stephenson, S. L., 1996. Ecological studies of slime molds (Dictyostelids and Myxomycetes) in the goil/litter microhabitat of the Luquillo Experimental Forest. Preliminary report (unpublished). USDA/Forest Serv, Forest Product Laboratory, Luquillo, Puerto Rico.

Stevenson, J. A., 1975. Fungi of Puerto Rico and the American Virgin Islands. BraunBrumfield Inc., Ann Arbor, Michigan.

Wadsworth, F. H., 1977. Reseña histórica de la Isla de Mona. Revista/Rev Interam 6:587-621.

Wiewandt, T. A., 1977. Ecology, behavior, and management of the Mona Island ground iguana, Cyclura stejnegeri. Ph.D. Dissertation, Cornell Univ, Ithaca, New York.

Woodbury, R. C., L. F. Martorell and J. G. Garcia-Tudurf, 1977. The flora of Mona and Monito Islands, Puerto Rico (West Indies). UPR-Agric. Exp. Stn. Bull. 252. 